\title{
Popularization of organic chilli cultivation in the Eastern Ghat high land zone of Odisha, India
}

\author{
P. Sial ${ }^{1}$, R. K. Tarai $^{2 *}$ and B. K. Sethy ${ }^{2}$ \\ ${ }^{1}$ High Altitude Research Station, Orissa University of Agriculture and Technology, Pottangi, Koraput -764039, \\ (Odisha), INDIA \\ ${ }^{2}$ College of Horticulture, Orissa University of Agriculture and Technology, Chiplima, Sambalpur-768026 (Odisha), \\ INDIA \\ *Corresponding author. E-mail: ranjanouat@gmail.com
}

Received: January 25, 2016; Revised received: June 17, 2016; Accepted: October 14, 2016

\begin{abstract}
The present study was conducted in the Koraput district of Odisha in India during 2012-13 and 2013-14 under National Horticulture Mission for popularization of organic chilli cultivation through frontline demonstrations. The green chilli yield of hybrid Guntur Hope varied from 5.0 t/ha to $6.67 \mathrm{t} / \mathrm{ha}$ in different FLD organic plots, where as it varied from 5.75 t/ha to $6.83 \mathrm{t} / \mathrm{ha}$ in inorganic plots (Farmers Practice). The average yield in organic plots was $6.29 \mathrm{t} / \mathrm{ha}$ in comparison with average yield $6.52 \mathrm{t} / \mathrm{ha}$ of inorganic plots in farmers practice. The average cost of cultivation per ha of chilli on FLD plots was Rs.46, 100/- as against Rs. 43,400/- on inorganic plots (Farmers Practice). The cost of chilli cultivation in organic farming was comparatively higher than the conventional practice because of use of bio inputs in the field. However, the averages net return of Organic chilli in different FLD plots was Rs. 58,167/- in contrast to Rs. 43,107/- in inorganic chilli. The organic farming recorded higher net return than that of the Farmers Practice. The B:C ratio was found to be 1: 2.28 in Organic chilli and 1: 2.00 in Inorganic chilli. Organic chilli growers were highly satisfied with their organic production and economic return. Chilli farmers were advised to switch over to organic farming which can give high return and minimize environmental degradation.
\end{abstract}

Keywords: B:C ratio, Chilli, Cost of production, Gross return, Net return, Organic cultivation, Yield

\section{INTRODUCTION}

Chilli (Capsicum spp.) is an important commercial spices and vegetable crop for small and marginal farmers in Asia, Africa and South America. Throughout the world, chili is consumed fresh, dried or in powder (ElGhoraba et al., 2013). Most of the Indian chillies belong to the Capsicum annuum species and thus constitute the major spices used as food flavouring agent (Bokkisam et al., 2010). Pungency and colour are the two important characters liked by consumers. According to an estimate in 2012, chillies (dry-red and freshgreen fruits) were cultivated on 801,500 ha with a total production of 1.3 million $t$ of dry fruits and $6800 \mathrm{t}$ of fresh fruits in India. Average yield of dry chilli harvest was around $1.6 \mathrm{t} / \mathrm{ha}$ compared to those of $8.5 \mathrm{t} / \mathrm{ha}$ for green chilli (FAOSTAT, 2012). In India, the states of Andhra Pradesh, Karnataka, Maharashtra, Orissa and Tamil Nadu account for more than $75 \%$ of the area and total production of chilli. Organic farming offers solutions for sound rural development providing healthy food and earning more money through export. There are several positive evidences in the literature supporting organic farming (Buys, 1993). High quality organic foods are market openers for both national and international markets. The demand for organic produce in global market is very high. Organic agriculture is a production system which avoids or excludes the use of synthetic preparation-artificial fertilizers, pesticides, growth accelerators and fodder additives. Cost of organic products is 2-3 times higher than the conventional ones depending on the product and country (Patel et al., 2015). The increasing demand for organic products and scope for export opportunity has opened the eyes of farmers for practicing organic production practices (Patil et al., 2014). Frontline demonstration is a most suitable method for assessing the performance of improved technology with the existing technology, as it directly involves the scientists in conducting the demonstrations at the farmers' field which enables them to have first hand information related to technology (Rai et al., 2005). Catherine and Ivettte (2007) have observed that a shift to organic farming in developing countries can produce 80 per cent of the present yield and in the developed countries; it can match up to 90 per cent of the yield. Kshirsagar (2008) has revealed that organic farming is a system of farm management to create an ecosystem which can achieve sustainable productivity without the use of external inputs like chemo-synthetic fertilizers and pesticides. However, no knowledge is available on various economic aspects of organic chilli with regards to poten- 
tial yield and profitability to farmers, etc. Therefore, the present study was taken up with the specific objectives of studying the comparative productivity, profitability and economics of chilli production under both organic and inorganic method.

\section{MATERIALS AND METHODS}

Location: The investigation was carried out in Koraput district of Odisha in India as the organic cultivation of vegetable is practiced largely in the district. The chilli crop was selected for the study as large number of farmers practise the organic cultivation of chilli. The rainfall was recorded as $1518.2 \mathrm{~mm}$ and during the cropping season it was recorded as $1410.8 \mathrm{~mm}$. There is no dry spell observed during the investigation period.

Front line demonstration: The present study was conducted during 2013-14 in the Eastern Ghat High Land zone of Koraput district of Odisha in India under National Horticulture Mission for popularisation of organic chilli cultivation through frontline demonstrations. Frontline demonstration is a most suitable method for assessing the performance of improved technology with the existing technology, as it directly involves the scientists in conducting the demonstrations at the farmers' field which enables them to have first hand information related to technology. Also, skill trainings and exposure field visits were organized for skill up gradation of farmers in cultivation of chilli. After preliminary survey, 15 randomly selected farmers were selected with adopted method of organic chilli cultivation. A total 15 frontline demonstrations were conducted at 15 farmer's fields. The front line demonstration was conducted by farmers' participatory approach as suggested by Naik et al. (2012) and Patel et al. (2015).

Organic method: To compare the costs involved, yields and the returns in organic and inorganic cultivation of chilli, 15 farmers each practicing cultivation of chilli were selected randomly. In the study area seeds of chillii hybrid Guntur Hope @ 750g/ha, FYM (Farm Yard Manure)@12.5 t/ha, Vermicompost@4t/ha, Neem cake@2.5 q/ha, Azotobacter@12.5 kg/ha, PSB @ 12.5 kg/ha, Potassium Mobilising Bacteria@12.5 kg/ ha and biopesticides like Trichoderma viride@500g and Pseudomonas fluorescens@500g were used. Five kg each of Azotobacter and Phosphate solubilising bacteria and Potash mobilizing bacteria were also incorporated with FYM as basal dose for 1 ha area. The seeds were treated with Trichoderma viridae and Psuedomonas fluorescens@10 g per kg of seed to prevent incidence of seedling rot in the nursery. The pest management by use of organic amendments which is considered as an ecologically viable proposition that avoids environmental pollution was adopted by the method suggested by Rajendran (1993). The chilli seedlings were raised in the nursery during February to March and transplanting was done during the months of April to May.

Seeds treated with $T$. viridae were sown and covered thinnly using sand. The seeds germinate in 5 to 7 days. About 40 - 45 days old seedlings were transplanted in the main field. A spacing of $60 \mathrm{~cm} \times 30 \mathrm{~cm}$ was provided with a plant population of about 22200 seedlings per acre. After 30-40 days of sowing, thinning and gap filling was done. About $300 \mathrm{~g}$ of seeds were used to raise the nursery for an acre of area. The farmers used farm yard manure and vermicompost at the time of transplanting by the way of broadcasting. Neem cake was applied at the time of transplanting by mixing with FYM and Vermicompost to control nematodes and root grubs. The crop was irrigated at critical stage of water requirement like flowering and fruit development. Generally weeding was done twice to keep the field free from weeds, the first at 20-25 days of transplanting and the other after 20-25 days of the first weeding. Neem oil was sprayed at the rate of $3 \mathrm{ml} / 1$ at 10-12 days interval after transplanting to control incidence of thrips and mites. All the shed fruits and part of inflorescence were collected and destroyed at regular intervals. Rouging and destruction of affected plants were done to check the mosaic virus. For effective control of diseases like fruit rot and die back, $10 \mathrm{~g}$ each of $T$. viridae or $P$. fluorescens per litre of water were used for spraying. Mix spraying of $T$. viridae and $P$. fluorescens was done four times at 20 days interval starting from 20 days after transplanting.

Inorganic method: In case of farmers' practice (Inorganic method), the spacing, variety, planting time and the cultural practices were the same as adopted under organic chilli cultivation. However, the crop under conventional practices was raised with very subsistence inputs and without any seed treatment. Seeds of chilli were directly sown in the field without any treatment by the farmers. In inorganic cultivation of chilli, seeds, farm yard manure, urea, DAP fertilizers and plant protection chemicals which included monocrotophos, mancozeb, carbandizam and dimethoate were used in the inorganic cultivation of chilli. Under the inorganic cultivation also the chilli seedlings were raised in the nursery and then transplanted to the main field. About $300 \mathrm{~g}$ of seeds were used to raise the nursery for an acre of area. The farmers used about FYM (10 t/ha), Urea@ 300 kg /ha (50 per cent was applied as basal dose at the time of transplanting and remaining 50 per cent was top dressed at the flowering stage), DAP( about $150 \mathrm{~kg}$ per ha was applied at 5-6 weeks after transplanting). For plant protection monocrotophos@2 ml/1 was applied at 10-15 days interval after transplanting mainly to control fruit borer and thrips. Mancozeb was sprayed @ 2g/1 at 8-10 days interval at 3 weeks after transplanting to control leaf spot disease, Sulfex was used@3 g / 1 to control powdery mildew disease and imidacloprid@1 @ $1 / 1$ was sprayed at 3 weeks interval to control sucking pests like thrips and mites.

Data recording: Data on yield $\mathrm{ha}^{-1}$, cost of production 
(Rs ha ${ }^{-1}$ ), gross return (Rs ha $\left.{ }^{-1}\right)$, net return $\left(\mathrm{Rs} \mathrm{ha}^{-1}\right)$ and $\mathrm{B}: \mathrm{C}$ ratio were taken in both organic and inorganic method of chilli cultivation and were presented in the tables. The B: C ratio was calculated by using the formula Gross returns / Cost of cultivation. The data has been collected by the method suggested by Biswas et al. (2011) and Naik et al. (2012).

\section{RESULTS AND DISCUSSION}

The Front line demonstrations were conducted on organic cultivation of chilli with assistance under $\mathrm{Na}$ tional Horticulture Mission at different farmers field in Koraput district of Odisha in India (Table1).The selection of farmers was made in consultation with the local Assistant Agriculture Officers of Pottangi and Semiliguda and Scientists of Krishi Vigyan Kendra,

Table 1. Area allotment under front line demonstrations on organic chilli cultivation during 2013-14.

\begin{tabular}{cccc}
\hline S. N. & Farmer & FLD Area (ha) & $\begin{array}{c}\text { Name of Hy- } \\
\text { brid Seed }\end{array}$ \\
\hline 1 & Farmer 1 & 0.4 & Guntur Hope \\
2 & Farmer 2 & 0.3 & Guntur Hope \\
3 & Farmer 3 & 0.25 & Guntur Hope \\
4 & Farmer 4 & 0.25 & Guntur Hope \\
5 & Farmer 5 & 0.35 & Guntur Hope \\
6 & Farmer 6 & 0.4 & Guntur Hope \\
7 & Farmer 7 & 0.3 & Guntur Hope \\
8 & Farmer 8 & 0.3 & Guntur Hope \\
9 & Farmer 9 & 0.3 & Guntur Hope \\
10 & Farmer 10 & 0.3 & Guntur Hope \\
11 & Farmer 11 & 0.3 & Guntur Hope \\
12 & Farmer 12 & 0.4 & Guntur Hope \\
13 & Farmer 13 & 0.4 & Guntur Hope \\
14 & Farmer 14 & 0.45 & Guntur Hope \\
15 & Farmer 15 & 0.35 & Guntur Hope \\
\hline
\end{tabular}

Koraput, Semiliguda in Odisha of India. The hybrid variety Guntur Hope seed was supplied to the farmers. The different organic inputs were supplied to FLD farmers to popularize the technology.

Yield: From the data presented in the Table 2 and Fig. 1 , it was revealed that the green chilli yield of hybrid Guntur Hope varied from $5 \mathrm{t} \mathrm{ha}^{-1}$ to $6.8 \mathrm{t} \mathrm{ha}^{-1}$ in different Front Line Demostrated organic plots, where as it varied from $5.75 \mathrm{t} \mathrm{ha}^{-1}$ to $6.83 \mathrm{t} \mathrm{ha}^{-1}$ in inorganic plots (Farmers Practice). The average yield in organic plots was $6.29 \mathrm{t} \mathrm{ha}^{-1}$ in comparison with average yield $6.52 \mathrm{t}$ $\mathrm{ha}^{-1}$ of inorganic plots in farmers practice. The higher yield in inorganic method than organic method of chilli cultivation was in close proximity with the findings of Patil et al. (2014) and Naik et al. (2012). Patil et al. (2014) obtained higher yield (17.3 t/ha) in inorganic method as against organic method $(13.3 \mathrm{t} / \mathrm{ha})$ in chilli. Similarly, according to Naik et al. (2012) organic cultivation of chilli recorded lower yield $(10.25 \mathrm{t} / \mathrm{ha})$ as compared to inorganic method (12.15 t/ha) under Belgaum district of Karnataka. The difference in yield obtained might be due to growing of chilli under different agroclimatic conditions. The result obtained was also in consonance with the findings of Bharadwaj et al. (2000), who reported that application of sole organic source of nutrients recorded 11 to $17 \%$ lower yield in different vegetable crops.

Cost of production: The cost of chilli cultivation in organic farming was comparatively higher than the conventional practice because of use of bio inputs in the field. Perusal of the data presented in the Table 3 and Fig. 2 indicated that the cost of production ranged from Rs.34000 to Rs.56000 ha ${ }^{-1}$ in farmers field under organic method of cultivation whereas it varied from

Table 2. Yield Performance of Organic chilli in comparison to Inorganic chilli cultivation at Eastern ghat high land zone of Odisha.

\begin{tabular}{cccccccc}
\hline S. & Name of the & Area (ha) & \multicolumn{3}{c}{$\begin{array}{c}\text { Plot yield of green chilli ob- } \\
\text { Nained after 10 harvests(q) }\end{array}$} & Yield of green chilli / ha (t) \\
\cline { 2 - 7 } & & FLD & FP & FLD & FP & FLD & FP \\
\hline 1 & Farmer 1 & 0.4 & 0.4 & 20 & 23 & 5.00 & 5.75 \\
2 & Farmer 2 & 0.3 & 0.3 & 18 & 20 & 6.00 & 6.67 \\
3 & Farmer 3 & 0.25 & 0.25 & 16 & 17 & 6.40 & 6.80 \\
4 & Farmer 4 & 0.25 & 0.25 & 17 & 16.7 & 6.8 & 6.68 \\
5 & Farmer 5 & 0.35 & 0.35 & 21.5 & 22 & 6.14 & 6.29 \\
6 & Farmer 6 & 0.4 & 0.4 & 24.5 & 25.2 & 6.13 & 6.30 \\
7 & Farmer 7 & 0.3 & 0.3 & 19.7 & 20 & 6.57 & 6.67 \\
8 & Farmer 8 & 0.3 & 0.3 & 19 & 19.5 & 6.33 & 6.50 \\
9 & Farmer 9 & 0.3 & 0.3 & 20 & 20.5 & 6.67 & 6.83 \\
10 & Farmer 10 & 0.3 & 0.3 & 19.5 & 20 & 6.50 & 6.67 \\
11 & Farmer 11 & 0.3 & 0.3 & 20 & 20 & 6.67 & 6.67 \\
12 & Farmer 12 & 0.4 & 0.4 & 24.6 & 25.5 & 6.15 & 6.38 \\
13 & Farmer 13 & 0.4 & 0.4 & 25.5 & 26 & 6.38 & 6.50 \\
14 & Farmer 14 & 0.45 & 0.45 & 26 & 27 & 6.50 & 6.75 \\
15 & Farmer 15 & 0.35 & 0.35 & 21.5 & 22 & 6.14 & 6.29 \\
& Average & 0.34 & 0.34 & 20.85 & 21.63 & 6.29 & 6.52 \\
\hline
\end{tabular}

FLD- Front Line Demonstration (Organic chilli cultivation); FP- Farmers Practice (Inorganic Chilli cultivation) 
P. Sial et al. / J. Appl. \& Nat. Sci. 8 (4): 1821-1826 (2016)

Table 3. Cost : Benefit analysis from organic chilli in comparison to inorganic chilli cultivation.

\begin{tabular}{|c|c|c|c|c|c|c|c|c|c|}
\hline \multirow[t]{2}{*}{$\begin{array}{l}\text { S. } \\
\text { N. }\end{array}$} & \multirow[t]{2}{*}{$\begin{array}{c}\text { Name of the } \\
\text { farmer }\end{array}$} & \multicolumn{2}{|c|}{$\begin{array}{c}\text { Total cost of produc- } \\
\text { tion (Rs.) } \\
\end{array}$} & \multicolumn{2}{|c|}{ Gross return (Rs.) } & \multicolumn{2}{|c|}{ Net return (Rs.) } & \multicolumn{2}{|c|}{ B:C ratio } \\
\hline & & FLD & FP & FLD & $\mathbf{F P}$ & FLD & $\mathbf{F P}$ & FLD & $\mathbf{F P}$ \\
\hline 1 & Farmer 1 & 56000 & 52000 & 100000 & 92000 & 44000 & 40000 & 1.8 & 1.8 \\
\hline 2 & Farmer 2 & 39500 & 37000 & 90000 & 80000 & 50500 & 43000 & 2.3 & 2.2 \\
\hline 3 & Farmer 3 & 34000 & 32000 & 80000 & 68000 & 46000 & 36000 & 2.4 & 2.1 \\
\hline 4 & Farmer 4 & 35000 & 32000 & 85000 & 66800 & 50000 & 34800 & 2.4 & 2.1 \\
\hline 5 & Farmer 5 & 50000 & 47000 & 107500 & 88000 & 57500 & 41000 & 2.2 & 1.9 \\
\hline 6 & Farmer 6 & 56000 & 52500 & 122500 & 100800 & 66500 & 48300 & 2.2 & 1.9 \\
\hline 7 & Farmer 7 & 42000 & 39000 & 98500 & 80000 & 56500 & 41000 & 2.3 & 2.1 \\
\hline 8 & Farmer 8 & 42000 & 39500 & 95000 & 78000 & 53000 & 38500 & 2.3 & 2.0 \\
\hline 9 & Farmer 9 & 40000 & 39000 & 100000 & 82000 & 60000 & 43000 & 2.5 & 2.1 \\
\hline 10 & Farmer 10 & 42000 & 39500 & 97500 & 80000 & 55500 & 40500 & 2.3 & 2.0 \\
\hline 11 & Farmer 11 & 42000 & 39500 & 100000 & 80000 & 58000 & 40500 & 2.4 & 2.0 \\
\hline 12 & Farmer 12 & 56000 & 53500 & 123000 & 102000 & 67000 & 48500 & 2.2 & 1.9 \\
\hline 13 & Farmer 13 & 56000 & 52000 & 127500 & 104000 & 71500 & 52000 & 2.3 & 2.0 \\
\hline 14 & Farmer 14 & 52000 & 51000 & 130000 & 108000 & 78000 & 57000 & 2.5 & 2.1 \\
\hline 15 & Farmer 15 & 49000 & 45500 & 107500 & 88000 & 58500 & 42500 & 2.2 & 1.9 \\
\hline & Average & 46100 & 43400 & 104267 & 86507 & 58167 & 43107 & 2.28 & 2.00 \\
\hline
\end{tabular}

Selling Price of organic green chilli= Rs 5000/-/q and inorganic green chilli= Rs 4000/-/q

FLD- Front Line Demonstration (Organic chilli cultivation); FP- Farmers Practice (Inorganic Chilli cultivation)

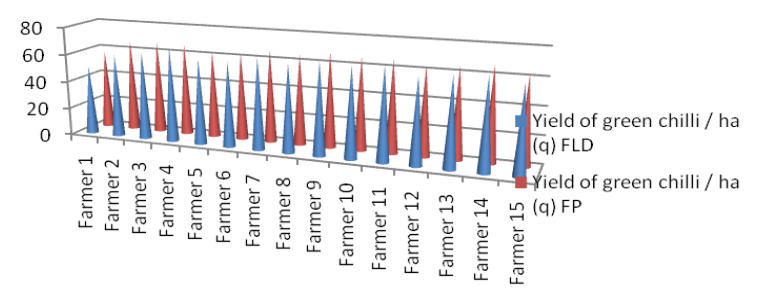

Fig. 1. Green chilli yield ( $q / h a)$ in front line demonstration and farmers practice.

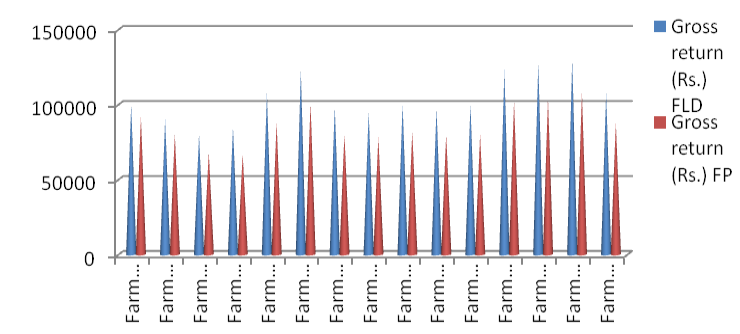

Fig. 3. Gross return (Rs/ha) in front line demonstration and farmers practice.

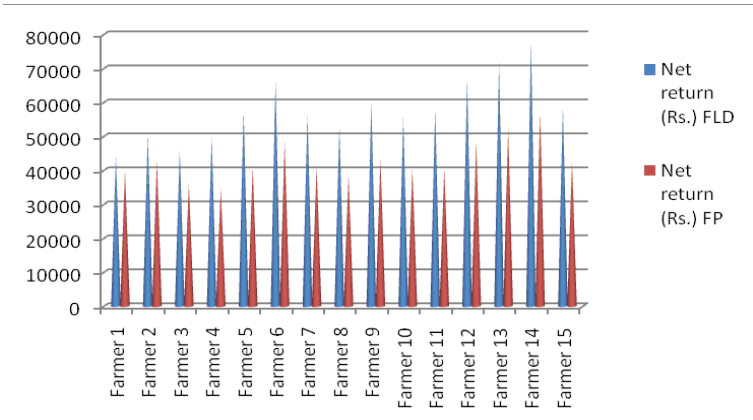

Fig. 5. Net return $(R s / h a)$ in Front Line Demonstration and farmers practice.

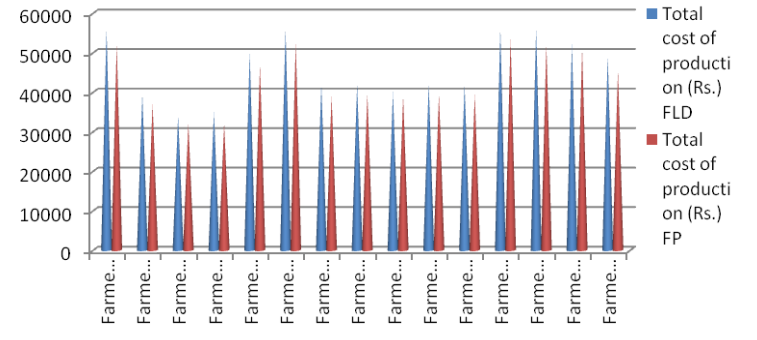

Fig. 2. Cost of production (Rs/ha) in front line demonstration and farmers practice.

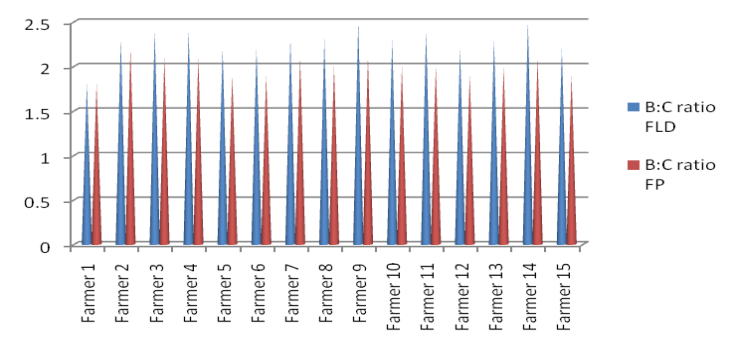

Fig. 4. Benefit: Cost ratio in front line demonstration and farmers practice.

Rs. 32000 to Rs. 53500 in the farmers field under inorganic method of cultivation. Similarly the average cost of cultivation per ha of chilli on Front Line Demonstrated plots was Rs.46100 as against Rs. $43400 \mathrm{ha}^{-1}$ from inorganic plots (Farmers Practice). The expenditure on organic manures was found to be an important item in total cost of cultivation on organic fields whereas in the cost of cultivation of chilli on inorganic fields the expenditure on chemical fertilizers was found to be an important item in the total cost of cultivation on inorganic farms. The difference in cost of cultivation between organic farming and inorganic farming was marginal. The result was also supported 
by the findings of Sonawane et al. (2015) who reported higher cost for production in organic method of cultivation in okra (Rs. 2,67,861 ha $\mathrm{ha}^{-1}$ ) as compared to inorganic method (Rs. 2,52,496 ha-1) under Western Maharashtra condition.

Gross return: From the data depicted in the Table 3 and Fig. 3, it is obvious that the gross return varied from Rs.80000 to Rs. $130000 \mathrm{ha}^{-1}$ in different farmers filed under organic plots. Similarly it varied from Rs.68000 to Rs. $108000 \mathrm{ha}^{-1}$ in different farmers field under inorganic plots (Farmers practice). The average gross return was found to be Rs.104267 and Rs.86507 $\mathrm{ha}^{-1}$ from organic and inorganic field respectively. Hence, the gross return was found higher in organic method as against the inorganic method of chilli cultivation. This result corroborates the earlier findings of Naik et al. (2012) who obtained higher gross return of Rs. $1,00,725 \mathrm{ha}^{-1}$ from organic method of chilli as compared to inorganic method (Rs. 76,458 ha-1) under North Karnataka condition.

Net return: The net return from different farmers field varied from Rs.44000 to Rs. $78000 \mathrm{ha}^{-1}$ and Rs. 34800 to $57000 \mathrm{ha}^{-1}$ from organic and inorganic plots of different famers respectively (Table 3 and Fig. 5). The average net return of Organic chilli in different FLD plots was found to be Rs. $58167 \mathrm{ha}^{-1}$ in contrast to Rs.43107 $\mathrm{ha}^{-1}$ in different farmers field under inorganic chilli cultivation. The organic farming recorded higher net return than that of the Farmers Practice. Though the yield levels on organically grown field were lower compared to inorganic farms the net returns were higher because of the premium price received.The result was in agreement with the finding of Patel et al. (2015) uner West Tripura condition and Naik et al. (2012) under North Karnataka condition. According to Patel et al. (2015) a higher net return of Rs. 2,97,000 ha ${ }^{-1}$ was obtained in organic chilli cultivation as against Rs. $2,46,000 \mathrm{ha}^{-1}$ in inorganic method of chilli cultivation under West Tripura condition. Similarly, Naik et al. (2012) obtained a net return of Rs. $45,568 \mathrm{ha}^{-1}$ in organic chilli as compared to Rs. $19960 \mathrm{ha}^{-1}$ in inorganic method of chilli cultivation under North Karnataka condition.

B : C ratio: The return structure in chilli clearly indicated that the average gross returns per ha were higher (Rs. $104267 \mathrm{ha}^{-1}$ ) on organic fields compared to that of inorganic fields (Rs. 86,507 ha ${ }^{-1}$ ) with a net return on both the categories of the farmers as Rs.58167 on organic field and was Rs. 43107 on inorganic fields respectively. The B:C ratio was found to be 2.28 in Organic chilli and 2.00 in Inorganic chilli (Table 3 and Fig. 4). Similar findings are also reported by Patil et al. (2014) who obtained a B:C ratio of 2.11 in organic method over inorganic method (1.90) of chilli cultivation under Belgaum district of Karnataka. Also according to Naik et al. (2012) a higher B:C ratio of 1.83 was obtained in organic chilli as against 1.35 in inorganic chilli.

\section{Conclusion}

From the present investigation, it was witnessed that the yield of chilli from organic field were found to be lower than inorganic farms. Though organic farming gave relatively lower yields in the initial years, its continuous practice will help to build up the soil fertility, thereby to get increased yield in the later years. The lower crop yield in organic chilli was well compensated by the higher price it fetched in the market. Hence it is advisable for the farmers to switch over to organic farming which minimizes the environmental degradation. An alternative method of crop management using organic method is also equally effective tool for crop management. The organic inputs were mostly produced on the farms by the farmers themselves. Organic chilli growers were highly satisfied with their organic production and economic return due to switch over to organic farming, which gave high return and also help in minimize environmental degradation. However, for sustainability, farmers should be in position to produce required organic inputs in their own field. Although, the use of organic manures is associated with such problems like slow in nutrient release, high $\mathrm{C}: \mathrm{N}$ ratio and pollution problem, however, its uses will somehow minimize total reliance on mineral fertilizers which are not only too costly for poor resource farmers to acquire, but are associated with problems relating to soil acidity, nutrient imbalance, inadequate supply of macro and micro nutrients and ineffectiveness due to the blanket method of application. The necessity of having an alternative method i.e. organic method which can function in a friendly ecosystem while sustaining and increasing the crop productivity is realized now. Hence, organic chilli cultivation is now recognized as the best known alternative to the conventional method of inorganic cultivation.

\section{REFERENCES}

Bhardwaj, M. L., Harender Raj and Koul, B. L. (2000). Yield response and economics of organic sources of nutrients as substitute to inorganic sources in tomato, okra, cabbage and cauliflower. J. Agric. Sci., 70(10):653-656

Biswas, R.K., Majumder, D. and Sinha, A. (2011). Impacts and constraints in evaluation of organic farming in West Bengal. Study No. 167, Agro-economic research centre, Visva-Bharati, Santiniketan, pp. 1-44

Bokkisam, H.B., Channal, H.B., Bidari, B.I. and Shashidhara, G.B. (2010). Effect of nutrient ratios on yield and economics of chilli (Capsicum annuum L.)cv. Byadgi Dabbi in vertisols of northern transitional zone of Karnataka. The Asian J. Hort.,4 (2) : 198-200

Buys, J.(1993). Conversion towards organic cultivation in Russia:a preliminary study. Biological Agricl Hort., 10: $125-140$

Catherine, B. and Ivettte, P. (2007). Organic farming. Renewable Agric.Food Systems J., 22 : 78-81

El-Ghoraba, A.H. El., Javedb, Q., Anjumb, F.M., Hamedc S.F. 
and H.A. Shaabana, H. A. (2013). Pakistani bell pepper (Capsicum annum L.): Chemical compositions and its antioxidant activity. Int. J. Food Prop., 16 (1) : 18-32

FAOSTAT (2012). http://faostat.fao.org/site/339/ default.aspx.

Kshirsagar, K.G. (2008). Impact of Organic Farming on Economics of Sugarcane cultivation in Maharashtra. Gokhale Institute of Politics and Economics, Pune.

Naik,V.R., Kunnal, L.B., Patil, S.S. and Gulegudda, S.S. (2012). Organic and inorganic cultivation of chilli and its marketing- An economic analysis. Karnataka, J. Agric. Sci., 25 (2): 203-207

Patel, L.C., Chakrabarty,S. and Googoi, A.K.(2015).Organic cultivation of chilli - an assessment in West Tripura district of Tripura. J. Eco-friendly Agric., 10 (1): 15-19
Patil, M., Bheemappa, A, Angadi, J.G. and Guledgudda, S.S. (2014) .A critical analysis on economics and constraints in adoption of organic vegetable cultivation in Belgaum district. Karnataka J. Agric. Sci., 27 (4) : 539541

Rai, M. Singh, N., Singh,B. and Singh, M. (2005). Performance of improved varieties of solanaceous vegetable crops at farmers' field in eastern Uttar Pradesh. Veg. Sci., 32 (1) : 69-72

Rajendran, M. (1993). Studies on management of bhendi (Abelomoschus esculentus L) .M.Sc (Ag.) Thesis, Tamil Nadu Agriculture Uni versity, Coimbatore, p. 136

Sonawane, K.G., Pokharkar, V.G. and Gulave, C.M. (2015). Organic Vs. Inorganic production and marketing of Okra in Western Maharashtra- An economic analysis. Int. J. Trop. Agric., 33 (2): 1911-1917 